\title{
PENGARUH DOSIS PUPUK KANDANG AYAM DAN PUPUK HAYATI TERHADAP PERTUMBUHAN DAN PRODUKSI MENTIMUN (Cucumis sativus L.)
}

\section{THE EFFECT OF CHICKEN MANURE AND BIOLOGICAL FERTILIZER ON THE GROWTH AND PRODUCTION OF CUCUMBER PLANT}

(Cucumis sativus L.)

\author{
Erfian Aulia Rasyid ${ }^{1}$, Kus Hendarto ${ }^{2}$, Yohannes C.Ginting ${ }^{2}$, Akari Edy ${ }^{2}$ \\ 1. Mahasiswa Jurusan Agroteknologi Fakultas Pertanian Universitas Lampung \\ 2. Dosen Jurusan Agroteknologi Fakultas Pertanian Universitas Lampung \\ E-mail: aulia.erfian94@gmail.com
}

\begin{abstract}
The research aims to determine the effect of chicken manure and biofertilizer Bio Max Grow (BMG) application on length of plant, number of leaves, number of branches, number of flowers, number of fruits, length of fruit, diameter of fruit, fruit weights of cucumber plant. This research was conducted at Sukabanjar Village, Gedong Tataan District, Pesawaran Regency on October 2018 - January 2019. This research uses a Randomized Block Design (RBD) that are arranged in factorial (4x2) with 3 group and there were 8 treatment combinations. The results showed provision of chicken manure at a dose of 15 tonnes per hectare able to increase production growth as indicated by the number of leaves, number of branches, fruit length, and fruit diameter.Biological fertilizer BMG application with a dose of 20 milliliters per liter give the best result in production per plot than without treatment on the number of leaves and branches of the plant.The highest production is gained in treatment of chicken manure at a dose of 0-15 tonnes per hectare with a dose of 20 milliliters per liter of BMG fertilizer applicationthan without treatment.
\end{abstract}

Keywords: cucumber, chicken manure, organic fertilizer.

\begin{abstract}
ABSTRAK
Penelitian bertujuan untuk mengetahuipengaruh pemberian pupuk kandang ayam dan komposjerami serta aplikasi pupuk hayati Bio Max Grow (BMG) pada pertumbuhan dan dan produksi tanaman mentimun. Penelitian ini dilaksanakan di Desa Sukabanjar, Kecamatan Gedong Tataan, Kabupaten Pesawaran pada Oktober 2018 Januari 2019.Penelitian menggunakan Rancangan Acak Kelompok (RAK) yang disusun secara faktorial ( $4 \times 2$ ) dengan tiga kelompok dan terdapat 8 kombinasi perlakuan.Hasil penelitian menunjukkan bahwa pupuk kandang ayam 15 ton/ha mampu meningkatkan pertumbuhan produksi yang ditunjukkan oleh jumlah daun, jumlah cabang, panjang buah, dan diameter buah.Pemberian pupuk hayati BMG memberikan hasil terbaik dengan dosis $20 \mathrm{ml} /$ L dibandingkan tanpa pemberian pada jumlah daun dan cabang tanaman.Produksi timun tertinggi diperoleh pada dosis pupuk kandang ayam $0-15$ ton/ha jika disertai aplikasi pupuk hayati $20 \mathrm{ml} / 1$ daripada tanpa pupuk hayati.
\end{abstract}

Kata Kunci :mentimun, pupuk kandang ayam, pupuk hayati. 


\section{PENDAHULUAN}

Mentimun (Cucumis sativus L.) merupakan tanaman semusim yang bersifat menjalar atau merambat dengan perantaraan alat pemegang yang berbentuk spiral. Tanaman mentimun berasal dari bagian utara India, yakni lereng Gunung Himalaya, yang kemudian berkembang ke wilayah Mediteran. Di kawasan Asia khususnya Indonesia, mentimun baru dikenal sekitar dua abad sebelum masehi. Di Jawa dan Sumatera, mentimun banyak ditanam di dataran rendah (Samadi, 2002). Badan Pusat Statistik (2018) memperoleh data bahwa telah terjadi penurunan hasil produksi mentimun dari tahun 2015 hingga tahun 2018 pada provinsi Lampung. Pada tahun 2015 produksi mentimun di Lampung mencapai 15.651 ton, tahun 2016 sebesar 16.493 ton, tahun 2017 sebesar 14.238 ton, dan tahun 2018 sebesar 10.601 ton. Berdasarkan data tersebut dapat dikatakan produksi mentimun di Lampung mengalami penurunan hasil produksi setiap tahunnya.Rendahnya hasil produksi mentimun ini disebabkan karena kesuburan tanah sangat rendah (marginal), khususnya Tanah Ultisol yang memiliki sifatsifat seperti penampang tanah yang dalam, reaksi tanah masam ( $\mathrm{pH}<4,5)$, kejenuhan $\mathrm{Al}$ tinggi dan kejenuhan basa rendah. Salah satu upaya yang dapat dilakukan untuk memperbaiki kesuburan tanah adalah suplai unsur hara melalui pemupukan.

Pemupukan dapat meningkatkan dan mempertahankan kesuburan tanah sehingga dapat menyediakan unsur hara yang diperlukan tanaman untuk mendorong pertumbuhan, meningkatkan produksi, dan memperbaiki kualitas hasil. Penggunaan pupuk anorganik memiliki efek reaksi yang cepat bagi tanaman, akan tetapi dalam jangka panjang akan mengeraskan tanah dan mengurangi kesuburannya (Dermiyati, 2015). Hal ini perlu disiasati dengan cara mengurangi penggunaan pupuk anorganik dengan menggunakan pupuk organik yang harganya lebih murah dan ramah lingkungan (Syukur, 2005). Ada berbagai jenis pupuk organik baik padat maupun cair dan salah satu contohnya yaitu pupuk kandang.

Pupuk kandang ayam mempunyai fungsi yang penting yaitu untuk menggemburkan lapisan tanah (top soil), meningkatkan populasi jasad renik, mempertinggi daya serap dan daya simpan air, yang seluruhnya dapat meningkatkan kesuburan tanah (Sutedjo, 2010).Pada kotoran ayam ditemukan bakteri seperti Lactobacillus achidophilus, Lactobacillus reuteri, Leuconostoc mensenteroides dan Streptococcus thermophilus, dan sebagian kecil Actinomycetes serta kapang (Suryani $\mathrm{dkk}, 2010)$.

Selain penggunaan pupuk organik, penggunaan pupuk hayati juga perlu dilakukan.Pupuk hayati yaitu pupuk yang memiliki kandungan utama berupa mahkluk hidup atau mikroorganisme yang menguntungkan bagi tanaman dan juga tanah. Kandungan mikroorganisme ini yang berada pada pupuk hayati akan mampu meningkatkan kandungan hara dalam tanah dengan mekanisme kerja tertentu sehingga dapat meningkatkan pertumbuhan dan juga perkembangan tanaman, serta mampu mengoptimalkan hasil panen (Simanungkalit, 2001).

Tujuan penelitian adalah untuk mengetahui pengaruh pemberian dosis pupuk kandang ayam dan 
aplikasi pupuk hayati BMG serta interaksi antara kedua faktor perlakuan terhadap pertumbuhan dan produksi tanaman mentimun (Cucumis sativus L. )

\section{BAHAN DAN METODE}

Penelitian ini akandilaksanakan di lahan Desa Sukabanjar Kecamatan Gedong Tataan Kabupaten Pesawaran Provinsi Lampung. Penelitianakan dilaksanakan pada Oktober 2018 hingga Januari 2019. Bahan yang digunakan pada penelitian ini yaitu: benih Mentimun Komandan F1, pupuk kandang ayam dengan kandungan hara yaitu $\mathrm{N}$ sebesar 3,22\%, P sebesar 9,34\%, dan K sebesar 0,218\%, dan pupuk hayati dengan merk dagang Bio Max Grow (BMG). Alat yang digunakan yaitu: cangkul, parang, ajir, tali rafia meteran, penggaris, selang air, jangka sorong, timbangan,sendok, tank sprayer, gelas ukur, gunting, pisau, dan alat tulis.

Penelitian menggunakan Rancangan Acak Kelompok (RAK) yang disusun secara faktorial (4x2) dengan tiga kelompok dan terdapat 8 kombinasi perlakuan.Faktor pertama dosis pupuk kandang ayam (P) terdiri dari empat taraf yaitu: tanpa pupuk kandang (P0), pupuk kandang ayam 5ha (P1), pupuk kandang ayam 10 ha (P2), dan pupuk kandang ayam 15 ha (P3). Faktor kedua aplikasi pupuk hayati (B) terdiri dari dua taraf yaitu: tanpa pupuk hayati (B0) dan aplikasi pupuk hayati $20 \mathrm{ml} / \mathrm{L}$ (B1). Jumlah tanaman sampel sebanyak 72 tanaman, tiap perlakuan yang sama di tiap ulangan diambil tiga sampel tanaman untuk diamati. Homogenitas ragam diuji dengan uji Bartlett dan additivitas data diuji dengan uji Tukey, kemudian data dianalisis dengan sidik ragam dan dilanjutkan dengan uji BNT pada taraf 5\%.Variabel yang diamati yaitupanjang tanaman, jumlah daun, jumlah cabang, jumlah bunga betina, panjang buah, diameter buah, jumlah buah, bobot perbuah dan bobot buah perpetak.

\section{HASIL DAN PEMBAHASAN}

Tanah ultisol sangat identik dengan minimnya kesuburan tanah, dimana salah satu upaya yang perlu dilakukan guna memperbaiki kesuburan tanah yaitu dengan penambahan unsur hara melalui proses pemupukan yang tepat. Pupuk merupakan bahan alami atau buatan yang ditambahkan ke tanah dan dapat meningkatkan kesuburan tanah dengan menambah satu atau lebih hara esensial.Selain itu juga pemupukan sangat penting dalam menunjang pertumbuhan tanaman dan hasil yang optimal terlebih penggunaan pupuk organik. Pemberian pupuk organik memiliki peran yang besar bagi pertumbuhan serta perkembangan tanaman dalam fase vegetatif dan fase generatif. Ketersediaan unsur hara bagi tanaman merupakan hal yang penting juga, oleh karenanya diadakanya pengaplikasian pupuk hayati yang bertujuan dalam meningkatkan kematangan pupuk organik.

\section{Pengaruh Pemberian Dosis Pupuk Kandang Ayam} terhadap Pertumbuhan dan Produksi Timun (Cucumis sativus L.)

Pertumbuhan dan produksi timun tertinggi diperoleh pada dosis pupuk kandang ayam 15 ton/ha untuk jumlah daun, jumlah cabang, panjang buah, dan diameter buah (Tabel 1). Hal ini diduga karena pupuk kandang ayam mampu meningkatkan $\mathrm{N}$ di dalam tanah, 
Tabel 1. Pengaruh dosis pupuk kandang ayam terhadap jumlah daun 6 mst, jumlah cabang, panjang buah, dan diameter buah.

\begin{tabular}{lcccc}
\hline $\begin{array}{c}\text { Dosis pupuk kandang } \\
\text { ayam }\end{array}$ & Jumlah daun 6 mst & Jumlah cabang & Panjang buah & Diameter buah \\
\hline Tanpa dosis & $19,72 \mathrm{~d}$ & $1,72 \mathrm{~d}$ & $14,23 \mathrm{c}$ & $3,83 \mathrm{~b}$ \\
Dosis 5 ha & $25,89 \mathrm{c}$ & $2,17 \mathrm{c}$ & $15,46 \mathrm{~b}$ & $4,09 \mathrm{a}$ \\
Dosis 10 ha & $27,11 \mathrm{~b}$ & $2,39 \mathrm{~b}$ & $15,65 \mathrm{~b}$ & $4,12 \mathrm{a}$ \\
Dosis 15 ha & $28,39 \mathrm{a}$ & $3,00 \mathrm{a}$ & $16,35 \mathrm{a}$ & $4,16 \mathrm{a}$ \\
\hline BNJ 5\% & 0,74 & 0,18 & 0,44 & 0,07 \\
\hline
\end{tabular}

Keterangan: Nilai tengah yang diikuti oleh huruf yang sama tidak berbeda berdasarkan uji beda nyata jujur (BNJ) pada kolom yang sama pada taraf $5 \%$.

menurut Sidabutar(2006), bahan organik dari pupuk kotoran ayam merupakan makanan bagi mikroorganisme tanah yang sebagian besar terdapat mikroorganisme pengikat N. Berdasarkan hasil analisis yang telah dilakukan di Laboratorium Polinela pada tanggal 24 Juli 2019, bahwa pada pupuk kandang ayam yang digunakan terdapat kandungan hara yaitu pada $\mathrm{N}$ sebesar 3,22\%, pada $\mathrm{P}$ sebesar 9,34\%, K sebesar 0,218\%, serta kandungan C-Organik sebesar $13,11 \%$.

Pemberian beberapa dosis pupuk kotoran ayam juga mampu meningkatkan kelarutan $\mathrm{P}$ di dalam tanah.Hal ini diduga karena pemberian pupuk kotoran ayam pada tanah masam dapat menurunkan fiksasi $\mathrm{P}$ oleh kation asam di dalam tanah, sehingga ketersediaan P di dalam tanah meningkat. Menurut Evenson (1982) mengatakan bahwa mekanisme peningkatan berbagai P tersedia dari masukan bahan organik yang diberikan ke dalam tanah akan mengalami proses mineralisasi $\mathrm{P}$ sehingga akan melepaskan $P$ anorganik ke dalam tanah. Menurut Marsono dan Sigit (2001), fosfor sangat berperan dalam pembentukan bunga, buah, dan pematangan buah, namun fosfor juga mampu memperbaiki pembungaan dan pembuahaan.

Selain mengandung nitrogen dan fosfor yang cukup tinggi pupuk kotoran ayam juga mengandung kalium yang tinggi yang berperan penting dalam membantu pembentukan protein dan karbohidrat.Kalium juga berperan dalam memperkuat tubuh tanaman agar daun, bunga dan buah tidak mudah gugur.Hal ini yang membuktikan semakin tinggi dosis pupuk kandang ayam yang diberikan maka pertumbuhan vegetatif tanaman mentimun khususnya pertambahan jumlah daun semakin tinggi.

Pupuk kotoran ayam mampu meningkatkan kesuburan tanah, memperbaiki struktur tanah dengan pemantapan agregat tanah, aerasi, dan daya menahan air, serta kapasitas tukar kation.Bokashi yang berasal dari kotoran ayam mengandung sejumlah unsur hara dan bahan organik yang dapat memperbaiki sifat fisik, kimia, dan biologi tanah (Subhan dkk, 2008).Ketersediaan hara dalam tanah, struktur tanah dan tata udara tanah yang baik sangat mempengaruhi pertumbuhan dan perkembangan akar serta 
kemampuan akar tanaman dalam menyerap unsur hara.

Struktur tanah yang baik menjadikan perakaran berkembang dengan baik, sehingga semakin luas bidang serapan terhadap unsur hara maka tanaman timun akan mampu berproduktivitas dengan baik dan banyak menghasilkan buah (Notohadiprawiro dkk, 2006).

Pengaruh Aplikasi Pupuk Hayati terhadap Pertumbuhan dan Produksi Timun (Cucumis sativus L. )

Pemberian pupuk hayati $(20 \mathrm{ml} / \mathrm{L})$ dapat meningkatkan jumlah daun dan jumlah cabang daripada tanpa pupuk hayati (Tabel 2).Pupuk hayati Bio Max Grow banyak mengandung mikroorganisme yang sangat bermanfaat bagi tanaman. Menurut Gunarto (2005), menyatakan bahwa kandungan yang terdapat dalam Bio Max Grow adalah mikroba, enzim dan hormon seperti mikroba pelarut fosfat, mikroba selulolitik, enzim alkaline fosfatase, enzim acidfosfatase, hormone indole acetic acid, Azospirillium sp., Azotobacter sp., Lactobacillus sp., Pseudomonas sp, berbagai jenis kandungan mikroba tersebut memiliki perananya masing-masing seperti Azospirillium sp. dan Azotobacter sp. berperan pada fase vegetatif tanaman. Mikroba Tanaman yang diaplikasi dengan pupuk hayati berpengaruh terhadap panjang tanaman, jumlah daun, jumlah cabang, jumlah bunga betina, panjang buah, bobot perbuah, dan bobot buah per petak dibandingkan dengan tanaman tanpa diaplikasi pupuk hayati.Menurut Simanungkalit(2001), pemberian pupuk hayati dengan Bio Max Grow yang mengandung Azospirillumsp. dan Azotobactersp. dapat memfiksasi nitrogen secara bebas dari udara, menyebabkan unsur $\mathrm{N}$ dapat digunakan oleh tanaman guna meningkatkan jumlah cabang produktif.

Aplikasi pupuk hayati menghasilkan produksi buah perpetak yang lebih bamyaksebesar 6183,89 gram/petak dibandingkan tanpa aplikasi pupuk hayati sebesar 5516,26 gram/petak (Tabel 3). Hal ini terjadi karena penggunaan aplikasi pupuk hayati mampu meningkatkan kesuburan tanah. Penambahan pupuk hayati ke dalam tanah akan mempengaruhi kandungan unsur hara dalam tanah, dimana kandungan tersebut akan diserap oleh akar tanaman untuk dijadikan sebagai nutrisi dalam proses fotosintesis (Hindersah dan Simarmata,2004). Unsur hara tersebut dapat diserap dan tersedia oleh akar tanaman setelah melalui proses dekomposisi yang dilakukan oleh

Tabel 2. Pengaruh pupuk hayati terhadap jumlah daun 6 mst dan jumlah cabang.

\begin{tabular}{lcc}
\hline \multicolumn{1}{c}{ Aplikasi pupuk hayati } & Jumlah daun 6 mst & Jumlah cabang \\
\hline Tanpa aplikasi & $24,36 \mathrm{~b}$ & $2,08 \mathrm{~b}$ \\
Aplikasi $20 \mathrm{ml} / \mathrm{L}$ & $26,19 \mathrm{a}$ & $2,56 \mathrm{a}$ \\
\hline BNJ 5\% & 1,04 & 0,25 \\
\hline
\end{tabular}

Keterangan: Nilai tengah yang diikuti oleh huruf yang sama tidak berbeda berdasarkan uji beda nyata jujur (BNJ) pada kolom yang sama pada taraf 5\%. 
Tabel 3. Pengaruh dosis pupuk kandang ayam dan pemberian pupuk hayati terhadap variabel bobot buah perpetak.

\begin{tabular}{ccccc}
\hline \multirow{2}{*}{ Perlakuan } & \multicolumn{4}{c}{ Dosis Pupuk Kandang Ayam } \\
\cline { 2 - 5 } & Tanpa Dosis & Dosis 5 ha & Dosis 10 ha & Dosis 15 ha \\
& $(\mathrm{P} 0)$ & $(\mathrm{P} 1)$ & $(\mathrm{P} 2)$ & $(\mathrm{P} 3)$ \\
\hline Tanpa pupuk hayati & $5516,26 \mathrm{~B}$ & $6426,97 \mathrm{~B}$ & $6835,68 \mathrm{~A}$ & $7009,22 \mathrm{~B}$ \\
(B0) & $\mathrm{c}$ & $\mathrm{b}$ & $\mathrm{a}$ & $\mathrm{a}$ \\
Aplikasi pupuk hayati 20 m1/L & $6183,89 \mathrm{~A}$ & $6743,78 \mathrm{~A}$ & $6904,94 \mathrm{~A}$ & $7236,34 \mathrm{~A}$ \\
(B1) & $\mathrm{c}$ & $\mathrm{b}$ & $\mathrm{b}$ & $\mathrm{a}$ \\
\hline BNJ 5\% & \multicolumn{5}{c}{187,51} \\
\hline
\end{tabular}

Keterangan:

Angka sebaris yang diikuti huruf kecil yang sama menunjukkan tidak berbeda nyata pada taraf $5 \%$.

Angka sekolom yang diikuti huruf besar yang sama menunjukkan tidak berbeda nyata pada taraf 5\%.

mikroorganisme yang ada pada pupuk hayati. Hasil yang diperoleh dari proses fotosintesis tersebut akan mempengaruhi pertumbuhan serta hasil dari produksi tanaman mentimun.

\section{Pengaruh Interaksi Pemberian Dosis Pupuk} Kandang Ayam dan Aplikasi Pupuk Hayati pada Pertumbuhan dan Produksi Timun (Cucumis sativus L. )

Berdasarkan hasil penelitian yang telah dilakukan interaksi antara perlakuan dosis pupuk kandang ayam dan pupuk hayati Bio Max Grow nyata terhadap bobot buah perpetak.Keadaan ini menunjukkan bahwa antara perlakuan dosis pupuk kandang ayam dengan pupuk hayati mampu mempengaruhi produksi buah perpetak tanaman mentimun.Selama pertumbuhan dan perkembangan tanaman terdapat berbagai proses pertumbuhan yang intensitasnya berbeda-beda, yang berarti sepanjang pertumbuhan, kebutuhan unsur hara yang banyak dibutuhkan oleh tanaman.
Pemberian aplikasi pupuk kandang ayam dengan pupuk hayati Bio Max Grow, mampu memberikan hasil produksi yang lebih tinggi pada tanaman timun. Pupuk kandang ayam memiliki kandungan unsur hara makro dan mikro yang cukup tinggi serta mampu memberikan sumber nutrisi bagi kehidupan mikroorganisme tanah, menurut Sidabutar (2006), bahan organik dari pupuk kotoran ayam merupakan makanan bagi mikroorganisme tanah yang sebagian besar terdapat mikroorganisme pengikat $\mathrm{N}$. Pupuk hayati meningkatkan dekomposisi pupuk organik karena mengandung berbagai jenis mikroba, menurut Gunarto (2015), pupuk hayati mengandung berbagai jenis mikroorganisme fungsional seperti, Azospirillumsp.danAzotobactersp. sebagai fiksasi N, mikroba pelarut fosfat serta Pseudomonassp.

Hasil penelitian menunjukkan bahwa penggunaan dosis pupuk kandang ayam 15 ha dengan pupuk hayati $20 \mathrm{ml} / \mathrm{L}$ menghasilkan produksi yang paling tinggi sebesar 7236,34 gram/petakbila 
dibandingkan dengan tanpa perlakuan/kontrol sebesar 5516,26 gram/petak (Tabel 3), hal ini dikarenakan pada pupuk kandang ayam mampu memperbaiki sifat fisik, kimia, dan biologi tanah, selain itu juga dapat meningkatkan ketersediaan unsur hara tanah karena pada kotoran ayam memiliki kandungan unsur hara $\mathrm{N}$, $\mathrm{P}$ dan $\mathrm{K}$ yang cukup tinggi terutama pada unsur fosfor. Pemberian pupuk hayati mampu mempercepat proses dekomposisi unsur hara agar dapat diserap dan tersedia oleh akar tanaman yang dilakukan oleh mikroorganisme.

Proses interaksi yang terjadi antara pupuk kandang ayam dengan pupuk hayati yaitu pemberian pupuk kandang ayam mampu meningkatkan bahan organik yang ada didalam tanah yang befungsi sebagai sumber nutrisi bagi mikroorganisme. Pemberian pupuk hayati mampu meningkatkan jumlah mikroorganimse, dengan tersedianya sumber nutrisi bagi tersebut, maka mikroorganisme dapat bekerja secara maksimal dalam meningkatkan proses dekomposisi pupuk kandang ayam agar unsur hara yang dimiliki dapat diserap langsung oleh tanaman guna mampu meningkatkan pertumbuhan serta perkembangan dan hasil produksi.

\section{KESIMPULAN}

(1) Pupuk kandang ayam 15 ton/ha mampu meningkatkan pertumbuhan produksi yang ditunjukkan oleh jumlah daun, jumlah cabang, panjang buah, dan diameter buah.

(2) Pemberian pupuk hayati BMG memberikan hasil terbaik dengan dosis $20 \mathrm{ml} / \mathrm{L}$ dibandingkan tanpa pemberian pada jumlah daun dan cabang tanaman.

(3) Produksi timun tertinggi diperoleh pada dosis pupuk kandang ayam $0-15$ ton/ha jika disertai aplikasi pupuk hayati $20 \mathrm{ml} / \mathrm{L}$ daripada tanpa pupuk hayati.

\section{DAFTAR PUSTAKA}

Badan Pusat Statistik. 2018. Tanaman Hortikultura: Tabel Hasil Produksi Tanaman Ketimun Indonesia . https://www. bps.go.id/site/result Tab diakses pada tanggal; 15 Januari 2019 pukul 20.40 .

Dermiyati. 2015. Sistem Pertanian Organik Berkelanjutan. Plantaxia.Yogyakarta.121 hal.

Evenson, F.J.1982. Humus Chemestry.John Wiley and Sons.New York.512 hal.

Gunarto, L. 2015. Bio Max Grow Tanaman. Kementrian Pertanian Republik Indonesia. Jakarta. 56 hal.

Hindersah, R dan T Simarmata. 2004. Kontribusi rizobakteri Azotobacter dalam meningkatkan kesehatan tanah melalui fiksasi $\mathrm{N}_{2}$ dan produksi fitohormon di rizosfir. Jurnal Natur Indonesia. $6: 127-133$

Marsono dan P. Sigit, 2001.Pupuk Akar. Redaksi Agromedia. Jakarta. 114 hal.

Notohadiprawiro.2006. Pengelolaan Kesuburan Tanah dan Peningkatan Efisiensi Pemupukan.http://soil.faperta.ugm.ac.id/tj/ 1981/1984\%20penge.pdf. (Diakses tanggal 25 juli 2019). 
Samadi, B. 2002.Teknik Budidaya Mentimun Hibrida. Kanisius. Yogyakarta.63 hal.

Sidabutar, R. M. 2006. Pengaruh Pemberian Pupuk Organik terhadap Produksi Sawi (Brassica juncea L.) dan Beberapa Sifat Kimia Tanah Andisol.Skripsi.Universitas Sumatra Utara.Medan. 44 hal.

Simanungkalit, R. D. M. 2001. Aplikasi Pupuk Hayati dan Pupuk Kimia. Suatu Pendekatan Terpadu. Bul Agrobiol 4:56-61.

Subhan, F. Hamzah dan A. Wahab.2008. Aplikasi Bokashi Kotoran Ayam pada Tanaman Melon. Jurnal Agrisistem. 4(1):1-10.

Suryani, Isti, Agus Santoso, dan M. Juffrie. 2010. Penambahan Agar-Agar dan Pengaruhnya Terhadap Kestabilan dan Daya Terima Susu Tempe pada Mahasiswa Politeknik Kesehatan Jurusan Gizi. Yogyakarta: Jurnal Gizi Klinik Indonesia Vol. 7, No. 2 hal: 85-91.

Sutedjo, M. M. 2002. Pupuk dan Cara Pemupukan.Rineka Cipta. Jakarta. 177 hal.

Syukur.2005. Pengaruh Pemberian Bahan Organik terhadap Sifat-Sifat Tanah dan Pertumbuhan Caisin di Tanah Pasir Pantai. J.Ilmu Tanah dan Lingkungan 5 (1): 30-38. 